\title{
THE SUSTAINABLE MENTORING BY ENRICHING FUNCTIONAL FOOD CONTENT TO OVERCOME DISHARMONY AND SOCIETY'S ECONOMY VIA IPTEK-HUB LIPI CORNER
}

\author{
Tri Margono \\ Centre for Scientific Documentation and Information, Indonesian Institute of Sciences \\ JI. Jend. Gatot Subroto 10, Jakarta, 12710 \\ Correspondence: tri_margono@yahoo.com
}

\section{ABSTRACT}

The mentoring program for society who live in lagging area is very important. The main problem is how to handle the low economy of the society and the low numbers and competences of the extension workers in field of agricultural and fisheries-marine. Disharmony arises due to differences in the economic level of society so that conflicts of inter-ethnic and ethno-religion often occur. Iptek-Hub LIPI corner is the first pilot project of science-technology hub carried out by LIPI in lagging areas in Ketapang (West Borneo). This Hub is intended to address regional problems in order to minimize the science and technology gap for the society. The purpose of this study was to determine the form of social inclusions in science and technology. Sustainable mentoring for society as farmers through information diffusion programs is very important so that society could truly adopt information and technology transfer as a whole. Mentor as an expert assistance for society is needed to overcome the low of agricultural yields (cultivation) and the abundance of fisheries-marine (post-harvest) in this area. Therefore, increasing information content related to functional foods is very important to support the smooth process of mentoring activities. The results from bimtek (technical guidance) activities then break downed and described into matrix form as social inclusions. There are seven forms of social inclusions of society through the availability of Iptek-HUb LIPI corner, such as Iptek-Hub could: accommodate and well-catered information need of society; the availability of location/space as a meeting point for society to convey their problems is fulfilled properly; society be educated through teaching and learning activities; increased access information to information of appropriate technology; applied of appropriate technology information to improve society's economy; Improved society's literacy by provision of appropriate information; and enhancing society's empowerment through the creation of new innovations, especially on verified post-harvest products.

Keywords: Science and technology hub; Appropriate technology information; Functional foods; Ethnic conflict; Social conflict; Social integration; Meeting-point; LIPI corner; Ketapang; West Borneo; Indonesia

\section{INTRODUCTION}

Ketapang Regency is one of the lagging districts among 122 other lagging districts in Indonesia (Indonesia, 2015) during 2015-2019. There are 8 lagging districts in West Borneo, one of them is Ketapang Regency which a district located on the banks of Pawan River, with an area of $31,240.74 \mathrm{~km}^{2}$ and population of 495,090 people (Indonesia, 2018). Lagging area as explained in Presidential Regulation No.131 of 2015 (Indonesia, 2015) is a district where its population less developed compared to other districts on a national scale. The economic condition of Ketapang Regency during 2013-2017 shows changes in the structure and development of the region which derive from household consumption (Indonesia, 2018).

One of the weaknesses of the district is the difficulty of society in accessing information, especially related to development of the business which their managed. This causes the business competition that carried out from generation to generation not much progress. Besides that it also causes disharmony in 
business activities. In addition, the society's economy level does not develop due to lack of technology and innovation in product diversification. One way to overcome the gap in information access is through the development of science and technology hub. The main focus in provision of information through science and technology hub is information related to appropriate technology provided to society through mentoring activities. The mentoring program provided to society intended so that they can process and manage the products in accordance with the regional potential owned. This mentoring should be carried out gradually, continuously, and sustainable so that the product quality which produced could raise continuously in accordance with market demand.

\section{STUDY LEARNED}

\subsection{Mentoring Program}

Lagging areas are basically caused by economic problems. However, it is not only caused by economic aspect but also social, religious, cultural, ethnic and security aspects (even concerning the relationship between lagging areas and developed regions). Therefore the improving effort of society's welfare in lagging areas require great attention and partisanship from the government. Based on this, the development program of lagging areas should be focused on the acceleration of development in areas where social, cultural, economic, regional finance, accessibility, and infrastructure availability are still lagging other among areas. This condition is generally found in geographically isolated and remote areas such as border areas between countries, small islands, inland areas, and disaster-prone areas. Therefore, one of the priority programs that should be implemented is how to improve local economy through society empowerment via mentoring activities.

The mentoring program as explained by Aristonang (2001) is a society empowerment activity by involving experts as facilitators, communicators, motivators and dynamists. It is done to overcome the lack of number and extension worker competence in the field (Tri Margono \& Sugimoto, 2011). The mentoring program intended herein is aimed to mentor society be able to manage natural resources, especially sourced from agriculture or plantation and marine biota. In addition it also aims to improve the knowledge and skills of society so they be able to manage and diversify functional food materials into products which in accordance with nutritional standards. Diversification is aimed to raise food products quality that produced. Therefore this mentoring program includes mentoring activities for society to raise their abilities in an effort to improve the economy, as explained by Mashoed (2004). Further explained by Mashoed that the mentoring program can be carried out individually or through institution whose tasks and functions are to provide mentoring and training.

Mentoring programs aimed at society who live in lagging areas depend on society need, problems faced, and potential of local area. This program is an activity carried out in a structured, comprehensive and sustainable manner. The aim is to overcome the society problem of disharmony through positive and beneficial activity, to improve society economy, to improve and develop regional potential, and to improve the society knowledge and skills also product quality which produced through activity of managing and diversifying food products. Therefore the mentoring program is an integrated program and it is an integral unit interrelated between one and another to achieve self-sufficient of society. In the mentoring process, it is necessary to place a professional figure as the key to the success of the program implementation in the field, especially related to self-sufficient of society (Owin, 2006). The implementation of the mentoring program in principle starts from society organizing to society development which carried out continuously and sustainable so that the goal of improving the quality of functional food and the society economy can be achieved. It means disharmony problems that occur in society can be minimized through activities that more profitable such as mentoring program. 


\subsection{Functional Foods}

Functional food is widely developed by Food and Pharmaceutical Industries. Functional food has an effect on health. It also includes specified products made to improve physical and cognitive appearance (Wildman, 2001). It means functional food is a food that has a positive effect on one's health, physical and spiritual appearance in addition to the nutritional content and taste it has. So in this case the existence of a "special" factor for health is obtained due to the presence of active components in food ingredients and has a positive effect to improve society economy. This is evident after the Japanese food experts launched a concept known as FOSHU (Food for Specified Health Use), thus food is no longer only seen as a source of nutritious substances to meet basic needs for food to maintain health and fitness (Howlett, 2008). Some functional food requirements is food in the form of food or drink (not capsules, tablets or powders) which contain certain bioactive compounds and derived from natural ingredients; is food ingredients consumed from the daily diet and have certain functions after being consumed, especially in improving biological defense mechanism, preventing and restoring certain diseases, controlling physical and mental and slowing down the aging process (Saragih, 2014).

The tendency of functional food use in the world consumer level can be compared to the superiority of an area in development of a functional food category from the commercial side as is the results of research conducted by Jatraningrum (2009). From the global patent data, it is known that probiotics are the highest functional food category conducted in Europe and America, but in reality the market opportunities are not as high as the technological superiority. Unlike the category of food fiber material, the number of patents registered in this category is far below probiotics but the level of use of food fiber at the consumer level is very large and this is very promising to be developed in all regions of the world.

\subsection{Iptek-Hub LIPI Corner}

Science and Technology-Hub of LIPI corner was built and developed by LIPI to accommodate and meet the information needs of society who living in lagging areas; as a community meeting point to convey problems faced; building society capacity through teaching and learning activities; increasing access to information and the implementation of appropriate technology for the society so that their economy improve; improving society literacy by providing the right information; and improving society empowerment through creation of new innovations, especially in postharvest products through product diversification (Tri Margono et al, 2018).

Science and technology hub of LIPI Corner contains selected information in accordance with the needs of society. The information managed base on certain categories to facilitate so that it can be accessed easily. The content of functional food needs to be enriched to improve the quality of learning for experts as mentoring and to make it easy for society to implement appropriate technology and process of product diversification in the field. Information of appropriate technology is needed by society who living in lagging areas to improve product innovation and diversification. Based on some literatures explained that innovation has three components (Adam, 1988; Van Den Ban and Hawkins, 1996; Simamora, 2003; and Kotler, 2008), such as ideas, methods or practices, and products (goods and services). Furthermore be explained that in order to be called "innovation", the three components should have "new" properties. The "new" properties not always come from recent research result. The factor that influence the acceleration of adoption is the nature of innovation itself (Musyafak and Ibrahim, 2005). 


\section{METODOLOGI}

Research was conducted based on a literature study, Focus Group Discussion (FGD), and technical guidance. Result from literature study then used as basis for conducting a FGD with stakeholders in form of discussion. It is done to find out social inclusion along mentoring process carried out. Data obtained is then compiled in a table using the excel program then break down in the form of a matrix.

\section{DISCUSSIONS}

\subsection{Small and Medium Entrepreneurs (UKM) as Functional Food Managers in Ketapang Regency}

Small and Medium Entrepreneurs (UKM) in Ketapang district, West Borneo, still survive in the economic structure of society due to increasingly conducive and positive of local government policies. It can be shown by the increasingly of number and existence of UKM in the regions. Functional food managed by UKM in Ketapang district is dominated by plantation products (fruits such as durian) and marine resources (a type of shellfish). Internal factor more influence the development of UKM in an area like this, as stated by Hitt et al. (1999). Internal factor which intended is cultural factor. In this case, product processing is carried out for generations without any help of technology that complies with standard. Society use existing natural resources to run their businesses. Therefore the competitiveness of UKM in this area need to be increased optimally. An efforts to improve society competitiveness need to be done by considering the factors that can support its success. The factors intended are legality and institutional, political environment, social structure, and market structure (Figure 1). Another cultural factor is society habit in consuming domestic food products. This is in line with what Tambunan said (2006).

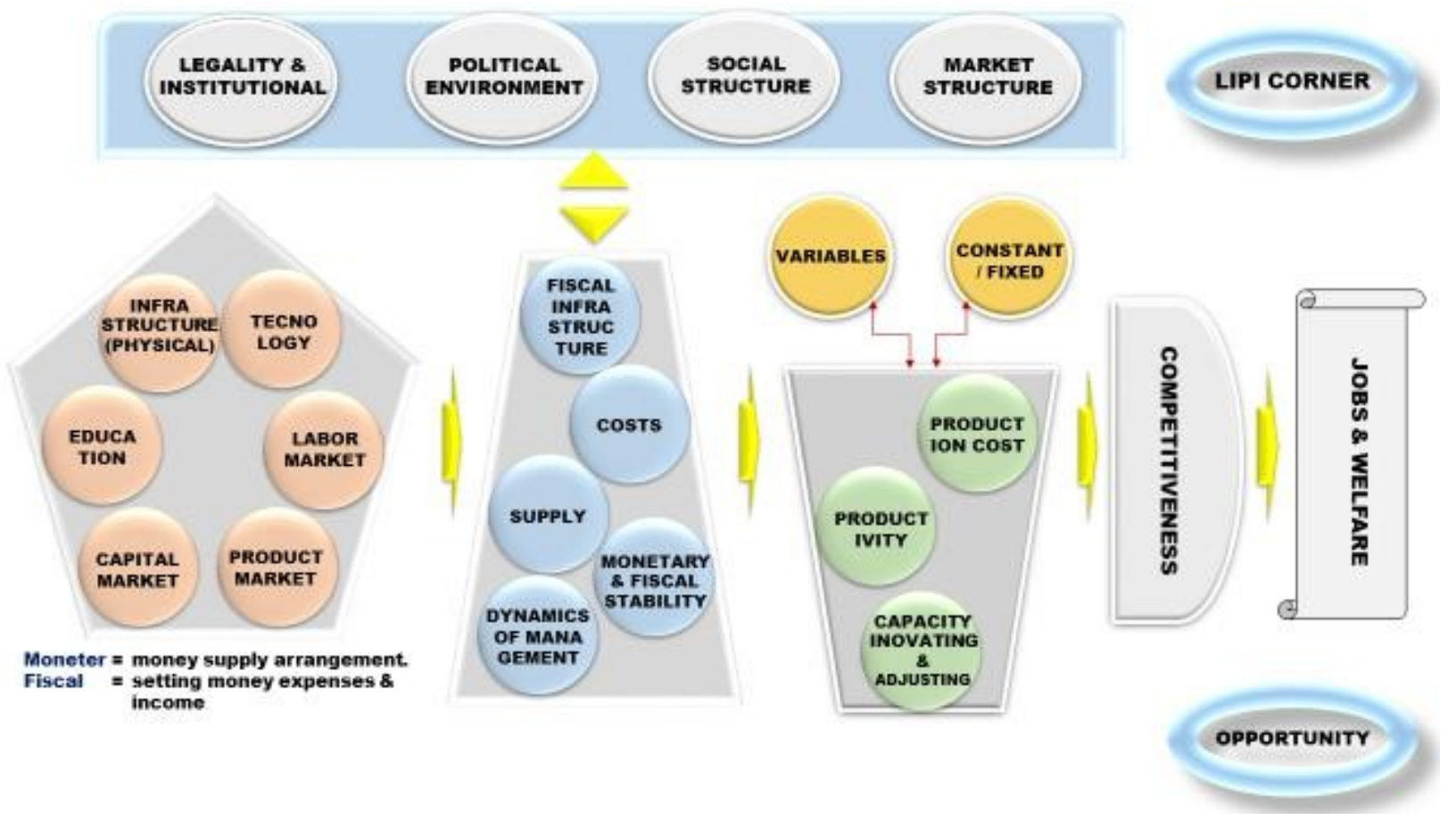

Figure 1. Determinants of UKM's Success

Functional food research innovations are increasingly developing through diversifying product processing and post-product management. The strategy of developing innovations carried out through a combination of planning in processing products with technology (including marketing) is very important, as suggested by Clark and Wheelwright (1993). However, it should be noted that dissemination of new innovation result is not easy to implement (Tri Margono, 2011). The innovation 
intended should translated into an easy language understandable by society so easily adopted and applied in the field.

\subsection{Access Information through Science and Technology-Hub LIPI Corner}

Access to information for teaching and learning activities is carried out through the Science Institute-Hub LIPI corner. Science and Technology-Hub built to overcome the information gap of society who live in lagging area. The Hub contains collection of appropriate technology information derived from research result which done in Indonesia. Information available on Iptek-Hub of Ketapang district be integrated with system of central LIPI at Jakarta. This is done so that information accessible easily by wider society in lagging areas without any obstacles (Figure 2 ).

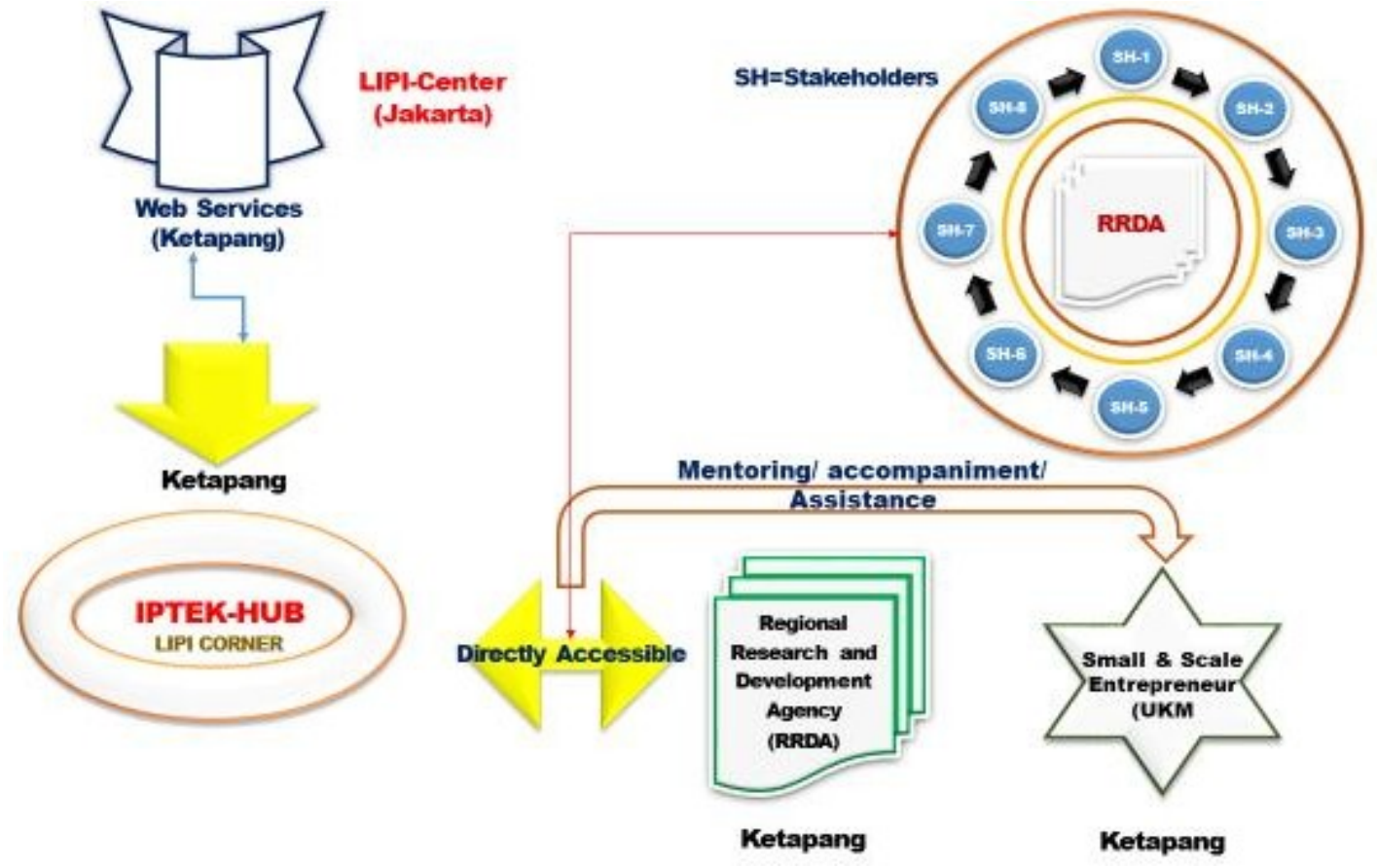

Figure 2. Information Access to Science and Technology-Hub LIPI Corner

Access to information Science and Technology LIPI Corner has 4 characteristics, such as Ondemand self-service, Ubiquitous network access, Location-independent resource pooling, and Rapid elasticity. Society can set its own quality and quantity of services needed without meet face to face with service provider. Everything is done according to user's wishes via internet network. Services can be accessed anytime and anywhere through an adequate internet network and through various types of client devices such as PCs, laptops, PDAs, and smartphones. The computing resources provided by service providers are multitenant, where it physically spread in various places and it used to serve many users in many scattered places. In addition, resource capabilities used by users such as server performance and large data storage can be easily managed by users according to their need.

\subsection{Social Inclusion}

Social inclusion that occurs along provision of Science and Technology LIPI corner are: 1) Society well accommodated and fulfilled their information need, 2) Location / space as a meeting point can used to convey society problems, 3) Society educated through mentoring programs via teaching and learning, 4 ) Society assisted with access to information on appropriate technology needed, 5) Society skill raise through training of appropriate technology application to improve their economy, 6) Society 
information literacy fulfilled well through provision of appropriate information, and 7) Society trained in efforts to create new innovation to diversify functional food products .

Social inclusion can be achieved through a process of identifying society needs carried out in detail and correctly so that it can provide solutions to problems faced by the society with appropriate innovations, as done by Sri Wahyuni (2000) and Nies (2000). Determinants factors that can improve society economy $(50 \%-150 \%)$ are through mentoring program, as Bunch stated (2001). Bunch further explained that innovation can increase productivity of local agricultural system and it can overcome the limitation factors existed in the system. The limitation factor is the most inadequate condition or prerequisite in a region. The adoption process occurs starting from introduction of an innovation (introduction) to society, then a mental process occurs to accept or reject the innovation. If the outcome of mental process is a decision to accept an innovation, the adoption of technology will occur. The process of technology adoption occurs through several stages, including: awareness, interest, evaluation, trial, adoption, and confirmation, as explained by Mundy (2000).

\section{CONCLUSION}

1. Society's disharmony in functional food business through UKM can be minimized through a sustainable mentoring program which done by empowerment and increasing of society skill.

2. Science and Technology-Hub LIPI corner that built is to bridge the society gap in information access of science and technology so that society economy in lagging area improved.

3. The mentoring program through Science and Technology-Hub LIPI corner can improve diversification and quality of functional food products and society economy development viaUKM.

\section{ANKNOWLEDGEMENT}

Author, in particular would like to thank the head of the Center for Scientific Documentation and Information-Indonesian Institute of Sciences, the LIPI corner team, the Functional Food team (Insinas

Program), the Regional Research and Development Agency team in Ketapang Regency, and the Team of the Ministry of Communication and Information Technology of Ketapang Regency

\section{REFERENCES}

Adams, M.E. 1988. Agricultural Extension in Developing Countries. First Edition. Singapore, Longman Singapore Publisher Pte Ltd.

Aritonang, Esrom; Hegel Terome; Syaiful Bahari. 2001. Pendampingan Komunitas Pedesaan. Jakarta, Sekretariat Bina Desa.

Bunch, Roland. 2001. Dua Tongkol Jagung: Pedoman Pengembangan Pertanian Berpangkal Pada Rakyat. Edisi ke dua. Jakarta, Yayasan Obor Indonesia.

Clark, K.B and Wheelwright, S.C. 1993. Managing New Product and Process Development: Text and Cases. New York, the Free Press

Goldberg I. 1994. Introduction. In: Goldberg I. (Ed.). Functional Foods. Designer Foods, Pharmafoods, Nutraceuticals. New York, Chapman \& Hall.

Hitt, Michael A.; R. Duane, Ircland and Robert, E. Hoskisson. 1999. Manajemen Strategi Manyongsong Era Persaingan dan Globalisasi. Cetakan Kedua. Jakarta, Erlangga.

Howlett J. 2008. Functional Food from Science to Health and Claims. ILSI Europe, Belgium.

Indonesia. 2015. Regulation of the Presidential No. 131 of 2015 about Stipulation of the Indonesian Lagging Area during 2015-2019 period. Jakarta.

Indonesia. 2018. Produk Domestik Regional Bruto Kabupaten Ketapang menurut Penggunaan 2013-2017. Ketapang, BPS. 69p

Jatraningrum DA. 2009. Functional Food Economic Opportunity: Patent data study and the processing technology. Prosiding Seminar PATPI. Jakarta. 
Kotler, P.H. 2008. Marketing Essentials. Moscow, Williams.

Mashoed. 2004. Pemberdayaan Masyarakat Miskin. Surabaya, Papyrus.

Mundy, Paul. 2000. Adopsi dan Adaptasi Teknologi Baru. Bogor, PAATP3.

Musyafak, Akhmad dan Ibrahim, Tatang M. 2005. Strategi Percepatan Adopsi dan Difusi Inovasi Pertanian Mendukung Prima Tani. Analisis Kebijakan Pertanian, 3 (1): 20-37.

Nies, Suk. 2000. Pemecahan Masalah dan Pengambilan Keputusan. Lembaga Administrasi Negara Republik Indonesia. Jakarta, LAN.

Owin, Jamasy. 2006. Profil Fasilitator. Sukabumi, LIPPI.

Saragih, Bernatal. 2014. Teknologi Pengembangan Pangan Fungsional. Prosiding Seminar Nasional Fakultas Teknik Jurusan Tata Boga Universitas Negeri Medan. Medan, 15 Februari.

Simamora, Bilson. 2003. Membongkar Kotak Hitam Konsumen. Jakarta, PT. Gramedia.

Soekartawi. 1988. Prinsip Dasar: Komunikasi Pertanian. Jakarta, UI Press.

Sri Wahyuni. 2000. Pemberdayaan Kelembagaan Mayarakat Tani Mendukung Percepatan Adopsi dan Keberlanjutan Adopsi Teknologi Usahatani Lahan Rawa. Makalah disampaikan pada Workshop Sistem Usahatani Lahan Pasang Surut-ISDP, Badan Litbang Pertanian, 26-29 Juni 2000. Bogor, Cipanas.

Tambunan, Tulus. 2006. Upaya-upaya Meningkatkan Daya Saing Daerah. Makalah Seminar. Pasca sarjana Universitas Sriwijaya

Tri Margono and Sugimoto, Shigeo. 2011. International Journal of Basic \& Applied Sciences IJBAS-IJENS, 11 (2): 80-86.

Tri Margono; Sri Hartinah, Abdurrakhman Prasetyadi, Wasi Tri Prasetya, Wahid Nashihuddin, Suparlan. 2018. Pembangunan dan pengembangan LIPI corner sebagai "iptek hub" di daerah: kabupaten ketapang (kalbar) sebagai percontohan. Laporan Kemajuan Tahap 1, Kegiatan Prioritas Nasional LIPI tahun 2018. LIPI. Jakarta, Pusat Dokumentasi dan Informasi Ilmiah LIPI. 27 p

Van Den Ban, A.W. and Hawkins, H.S. 1996. Agricultural Extension. Second Edition. New York, John Wiley \& Son, Inc.

Wildman, REC (2001). Handbook of Functional Food and Nutraceuticals. Boca Raton, CRC Press. ISBN 08493-8734-5. 